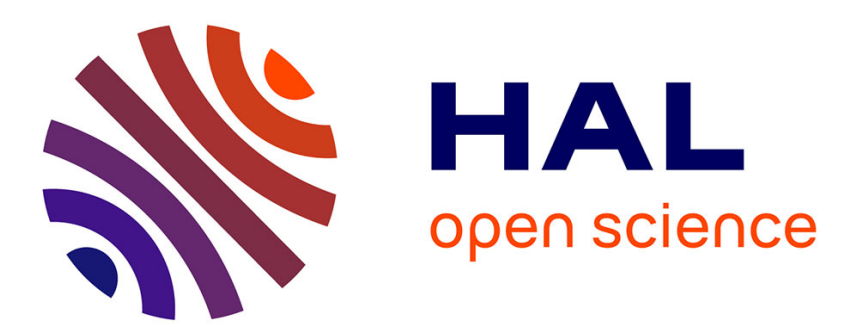

\title{
Dynamics of biofuel prices on the European market: Impact of the EU environmental policy on the resources markets
}

Francis Declerck, Jean-Pierre Indjehagopian, Frédéric Lantz

\section{To cite this version:}

Francis Declerck, Jean-Pierre Indjehagopian, Frédéric Lantz. Dynamics of biofuel prices on the European market: Impact of the EU environmental policy on the resources markets. 2020. hal-02487491v2

\section{HAL Id: hal-02487491 \\ https://essec.hal.science/hal-02487491v2}

Preprint submitted on 26 Feb 2020

HAL is a multi-disciplinary open access archive for the deposit and dissemination of scientific research documents, whether they are published or not. The documents may come from teaching and research institutions in France or abroad, or from public or private research centers.
L'archive ouverte pluridisciplinaire HAL, est destinée au dépôt et à la diffusion de documents scientifiques de niveau recherche, publiés ou non, émanant des établissements d'enseignement et de recherche français ou étrangers, des laboratoires publics ou privés. 


\section{ESSEC \\ BUSINESS SCHOOL}

DYNAMICS OF BIOFUEL PRICES ON THE EUROPEAN MARKET: IMPACT OF THE EU ENVIRONMENTAL POLICY ON THE RESOURCES MARKETS

FRANCIS DECLERCK, JEAN-PIERRE INDJEHAGOPIAN, FRÉDÉRIC LANTZ ESSEC RESEARCH CENTER

WORKING PAPER 2003

FEBRUARY 21, 2020

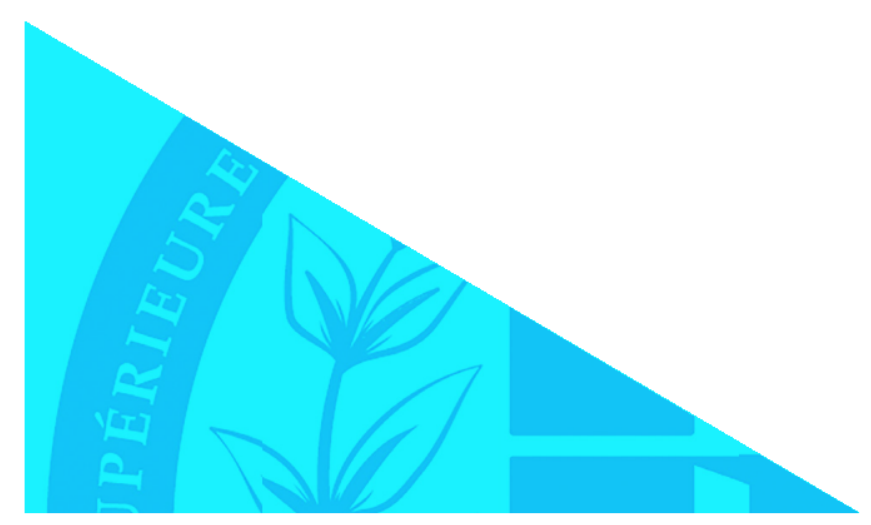




\title{
Dynamics of biofuel prices on the European market: \\ Impact of the EU environmental policy on the resources markets
}

Francis Declerck $^{(\mathrm{a})}$, Jean-Pierre Indjehagopian ${ }^{(\mathrm{b})}$, and Frédéric Lantz ${ }^{(\mathrm{c})}$

\begin{abstract}
This paper aims at explaining the major drivers of biodiesel market prices by examining agricultural resource prices and gasoil prices for automotive fuels in the context of the EU environmental policy. The EU policy has enhanced biodiesel production since 2006. Biodiesel prices are impacted by the EU policy as well as rapeseed and oil prices which have fluctuated a lot over the last decade. An econometric analysis was performed using monthly data from November 2006 to January 2016. However, tests for structural breaks show several changes in price behavior. This leads us to estimate a regime-switching model which reveals two main regimes for the biodiesel price pattern. When oil prices are high, biodiesel, rapeseed and diesel oil prices are related, mainly driven by oil prices. When oil prices are low, biodiesel prices are mostly related to rapeseed prices according to EU regulations requiring the blending of biodiesel and gasoil.
\end{abstract}

Keywords: biofuel, oil market, structural changes, switching regime model

JEL: O13, Q16, Q41, Q42

(a) Francis Declerck (corresponding author) is Associate Professor, Finance Department, ESSEC Business School, Paris campus, France.declerck@essec.edu

(b) Jean-Pierre Indjehagopian is Distinguished Emeritus Professor, Information Systems, Decision Sciences and Statistics (IDS) Department, ESSEC Business School, Paris campus, France. indjehagopian@essec.edu

(c) Frédéric Lantz is Professor, IFP-School, IFP-Energies Nouvelles, Rueil-Malmaison, France. frederic.lantz@ifpen.fr 


\section{INTRODUCTION}

This paper examines the links between biodiesel prices in Europe and prices of agricultural commodity resources and prices of gasoil used for automotive fuels. There is a lack of literature linking gasoil and biodiesel prices. The topic is original because it focuses on the dynamics of market price links to find a structural relationship between biodiesel and agricultural resources and gasoil. The paper focused on the European biodiesel market. EU biodiesel is mainly an ester processed from domestic rapeseed.

The use of biofuels has sharply increased in the EU since the 2003/30 EU Directive through financial incentives. Further national governments added tax constraints for refiners who do not blend diesel with biofuels. The 2003/30 Directive was replaced by the 2009 Renewable Energy Directive (RED) that was modified by the 2015/1513 Directive on the quality of automotive fuels.

Using monthly data from November 2006 to January 2016, no cointegration involving biodiesel, rapeseed and gasoil prices was found over the entire period. Several tests for breaks were performed. Unit-root tests with breaks were used: Zivot and Andrews (1992) tests enabled to find a break in the winter of 2008-2009, in December 2008 or February 2009. The Bai and Perron (1998) test for structural change in the relationship between biodiesel and diesel price was used. It led to the identification of five breaks involving a changing regime in March 2012, January 2014, March 2008, January 2009 and November 2010. These breaks matched strong movements on oil market prices. The two breaks in March 2012 and January 2014 were detected by different tests proposed by Bai and Perron. We decided therefore to use a regime-switching model in order to search for a relationship with a changing regime. We thus estimated the relationships between different variables, enabling us to find two different regimes.

Regime 1 is characterized by biodiesel prices driven more by gasoil prices than by rapeseed prices, in times of high oil prices: 2007-2008, late 2010 - late 2012. Regime 2 is characterized by biodiesel prices mainly driven by rapeseed prices in times of low oil prices: the year 2009, December 2010 - 2014. From that point in time, oil prices and agricultural (rapeseed and biodiesel) prices no longer moved quite in the same way. While oil prices dropped sharply, rapeseed and biodiesel prices have remained quite stable. Such new dynamics may be due to the annual harvest of agricultural oilseeds leading to shortterm price inelasticity of production and compulsory blending of biodiesel in fuels because of policy regulations.

The second section provides an economic and empirical analysis of the biodiesel market. The third section presents the review of the literature. The following section introduces the methodology and the data. The fifth section delivers and analyzes the results, which are discussed in the sixth section. Finally conclusions are drawn. 


\section{ECONOMIC AND EMPIRICAL ANALYSIS}

Biofuels are liquid or gaseous transport fuels made from biomass. In Europe, they serve as a renewable alternative to fossil fuels in the transport sector, contributing to a reduction in greenhouse gas emissions and improving the EU security of supply. The two major biofuels are biodiesel (11.1 million tons of oil equivalent Mtoe in 2015) and bioethanol (2.7 Mtoe). Biodiesel is the most common biofuel in Europe since diesel deliveries (211 Mtoe in 2015) amount to about 2.6 times gasoline deliveries (81.7 Mtoe). It comes from oils or fats after trans-esterification. It is a liquid consisting mainly of fatty acid methyl (or ethyl) esters, commonly named FAMEs. Among them, rapeseed methyl ester (RAME) is the major biodiesel in Europe. It is produced from rapeseed, an agricultural commodity mostly produced locally.

This policy is aimed at reducing the emissions of greenhouse gases and improving energetic independency among oil importing countries and supply security. It led to the emergence of biofuels in the 2000s. EU Parliament debates on farm land use resulted in revising the objectives of biofuel blending into automotive fuels in the 2000s, particularly during the 2008 crisis characterized by high agricultural prices.

The EU Renewable Energy Directive 2003/30/CE (EnR directive) on renewable has been enforced in 2006. In terms of energy content, the objective is to blend $5.75 \%$ of biodiesel in diesel used for transportation.

The 2003 and 2005 EU directives define the EU 'integrated climate and energy policy'. The latter sets out to achieve the following goals: (i) to increase energy supply security, (ii) to ensure the competitiveness of European economics and the availability of affordable energy supply, (iii) to promote the environmental viability and fight climate change. In 2008 the EU decided the '20-20-20 Initiative' with three main goals to be reached by 2020: cutting by $20 \%$ European greenhouse gas emissions from 1990 level, improving by $20 \%$ European energy efficiency and reaching a renewable energy share of $20 \%$ in the final energy consumption. This last objective has been updated by the EU Commission up to $27 \%$ in 2030 .

The 2009 Renewable Energy Directive (RED), slightly modified by the 2015/1513 Directive, sets constraining targets about renewable energy use in the final energy mix. It aims at blending at least 10\%, expressed in energy content, of biofuel in automotive fuels only by 2020 :

$-7 \%$ of $1^{\text {st }}$ generation biofuels from oilseeds (mainly rapeseed) or cereals (mainly soft wheat) or sugar beets.

- $3 \%$ that is twice $1.5 \%$ of $2^{\text {nd }}$ generation biofuels from biomass that cannot be used for food production (wood, leaves, straw and specific plants). 
To achieve these targets, the EU allows its member States to use different tools like green certificates and tax shelters.

Overall, biofuel production met up to $3.1 \%$ of global fuel needs for road transportation worldwide in $2014^{1}$. This share reached $4.7 \%$ within the EU in $2015^{2}$. Since 2010, biofuel consumption has stabilized at around 11 Mtoe for biodiesel and 2.7 Mtoe for bioethanol (figure 1). Increasing EU consumption is met by a growing domestic agricultural production and imports as pointed out by the rapeseed uses (Table 1). In 2016, EU rapeseed uses for biodiesel production accounted for $60 \%$ of EU rapeseed production.

Figure 1: Production of ethanol and biodiesel in Europe

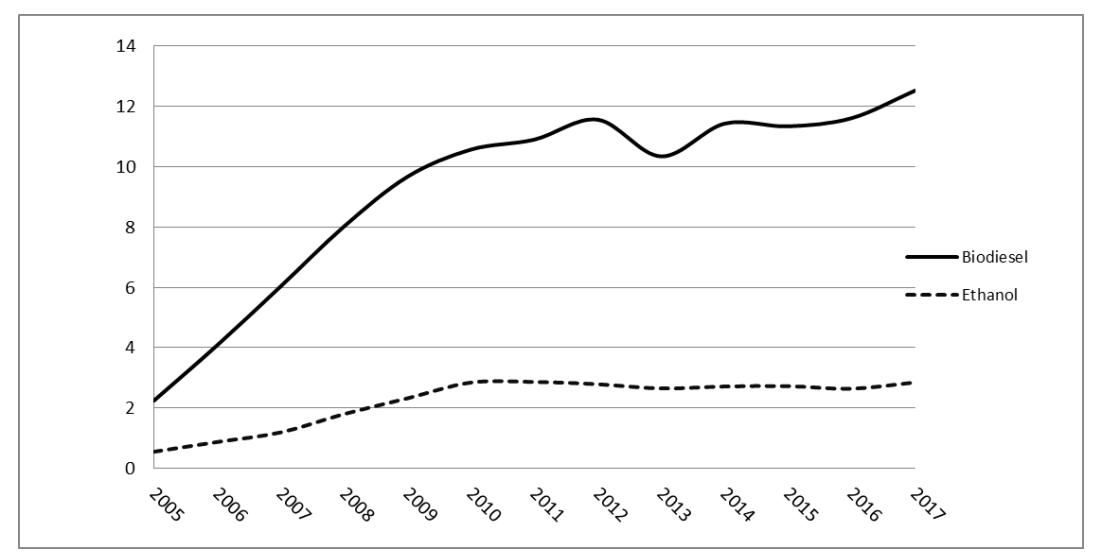

Unit: Mtoe

Source: Eurobserv'ER

Table 1 - The EU rapeseed use for biodiesel production from 2005 to 2016

\begin{tabular}{|c|c|c|c|c|c|c|c|c|c|c|c|}
\hline Crop year & $\begin{array}{l}07 / 2005- \\
06 / 2006\end{array}$ & $\begin{array}{l}07 / 2006- \\
06 / 2007\end{array}$ & $\begin{array}{l}07 / 2007- \\
06 / 2008\end{array}$ & $\begin{array}{l}07 / 2008 \text { - } \\
06 / 2009\end{array}$ & $\begin{array}{l}07 / 2009- \\
06 / 2010\end{array}$ & $\begin{array}{l}07 / 2010- \\
06 / 2011\end{array}$ & $\begin{array}{l}07 / 2011 \text { - } \\
06 / 2012\end{array}$ & $\begin{array}{l}07 / 2012- \\
06 / 2013\end{array}$ & $\begin{array}{l}07 / 2013- \\
06 / 2014\end{array}$ & $\begin{array}{l}07 / 2014 \text { - } \\
06 / 2015\end{array}$ & $\begin{array}{l}07 / 2015 \text { - } \\
06 / 2016\end{array}$ \\
\hline EU production & 15705 & 16165 & 18497 & 19025 & 21518 & 20619 & 19238 & 19172 & 20873 & 24127 & 21704 \\
\hline EU import & 369 & 431 & 685 & 3353 & 2082 & 2624 & 3752 & 3378 & 3524 & 2317 & 3220 \\
\hline EU export & 295 & 77 & 408 & 122 & 177 & 214 & 149 & 94 & 290 & 588 & 339 \\
\hline EU total use & 15778 & 16519 & 18775 & 22256 & 23423 & 23029 & 22840 & 22456 & 24107 & 25856 & 24585 \\
\hline
\end{tabular}

Unit: thousand tons

Source: Eurostat https://ec.europa.eu/eurostat/fr/web/agriculture/data/database

\footnotetext{
${ }^{1}$ BP (2016), BP Statistical Review of the World Energy, 48 p. www.bp.com/en/global/corporate/energyeconomics/statistical-review-of-world-energy.html (accessed 07.09.2017)

2 Eurobserv'ER (2016), Biofuel barometers, 7 p., www.eurobserv-er.org/category/barometers-in-english/ (accessed 07.09.2017)
} 
EU countries' blending targets are between $2.06 \%$ for Croatia and $7.57 \%$ for France. In this last case, the biofuel share reached around 7\% in 2014 with 0.4 Mtoe of ethanol and 2.5 Mtoe of biodiesel. Germany and France are the leading countries for biofuel production, each representing around $21 \%$ of EU production. Overall, in 2014, biofuel consumption amounted to about 11 Mtoe for biodiesel and 2.6 Mtoe for bioethanol in the European Union.

The EU energy policy was inspired by the Brazilian one. After the fourfold increase in oil prices in 1973, Brazil set up a program to replace imported fossil fuels by domestic renewable sources of liquid fuels: bioethanol from corn in the 1970s and biodiesel from soybean in 2004. In 2005, Brazilian law allowed blending $2 \%$ biodiesel to diesel. Biodiesel blending became mandatory in 2008. However, Sorda et al (2010), Padula et al (2012) questioned the economic efficiency of Brazilian biodiesel production because it is heavily supported by tax incentives and production and marketing subsidies.

The availability of crops and biomass is crucial to supplying the biofuel industry. Britz and Hertel (2011) use the CAPI model to show that the development of biofuel will lead to an expansion of crops. Carriquiry et al. (2010) point out that a large increase in the European biofuel supply will have some implications on agricultural markets. In this context, the analysis of the interactions between the oil market and biodiesel prices is a key point for the potential development of biofuel in Europe.

\section{REVIEW OF LITERATURE}

Since the beginning of the eighties, research has aimed at studying the potential of biofuels being disruptive to agricultural commodity prices and being affected by oil prices (Barnard, 1983). Filip et al (2017 provided a review of the literature on the relationship between energy prices and agricultural prices, using an econometric approach based on vector error correction models (VECM) and GARCH models focused on market volatility. They raised some questions about the relationships between energy prices, natural resources prices and biofuel prices. They also questioned the stability of such relationships over time.

Campiche et al. (2007) examined the co-movements between crude oil prices and corn, sorghum, sugar, soybeans, soybean oil, and palm oil prices during the 2003-2007 period through Johansen cointegration tests. The analysis revealed no cointegrating relationships over the full sample period. However, an analysis of the sub-sample over 2006-2007 revealed that soybean and corn prices were cointegrated with crude oil. Since the production of biodiesel has increased a lot from 2002, our analysis may provide better understanding about the links between rapeseed, biodiesel and gasoil markets. Natanelov et al. (2011) and Natanelov (2014) found co-movement of agricultural commodities (cocoa, coffee, corn, soybeans, sugar, etc.) and gold futures and crude oil prices using data from 1989 to 2011. They found 
strong a cointegration relationship between crude oil and gold prices. Focusing on biofuels, several authors have tried to link energy market prices and agricultural commodity market prices.

Harri et al (2009) found long-term equilibria in the agricultural and oil markets in the United States from a sample covering the period 2003-2007. Hertel and Beckman (2011) studied the relationship between these markets over the period 2001-2008 and focused on substitutions between inputs for bioethanol production. They highlight a phenomenon of volatility that they attribute to the blending obligations (blend wall) of bioethanol in gasoline. Peñaranda and Rupérez Micola (2011) studied the relationship between different commodity prices (soybean, corn, sugar, oil) over the period 1990-2011, highlighting the equilibrium between agricultural and oil prices with breaks, in using tests designed by Bai and Perron (1998, 2003a, 2003b). Peri and Baldi (2010) looked at the relationship between resource and diesel prices in Europe over the 2005-2007 period using a VECM econometric approach with threshold effect proposed by Balke and Fomby (1997). This found two thresholds in the price dynamics. Tyner (2010) offered a microeconomic analysis about the impact of bioethanol blending regulations on the bioethanol market price equilibrium during the oil price increase in 2008 .

Zhang et al. (2010) investigated the long-term equilibriums among agricultural commodity prices and their short-term dynamics using monthly data from March 1989 to July 2008. They found that sugar prices influenced all the other agricultural prices except rice. But they did not focus on oilseeds.

Ciaian and d'Artics (2011) used weekly data from January 1994 and confirmed that nine major agricultural commodity prices, including corn, wheat, rice, sugar, soybeans, cotton, banana, sorghum and tea, were interdependent with crude oil prices, even though some of those agricultural commodities were not used directly in biofuel production. Finally, Filip et al. (2017) used the same data set as the Zhang et al (2010) by extending it to 2016. Authors used a cointegration approach and detected several sub-periods they associated with the end of the agricultural market crises in 2008 and 2010.

Thus, the present research is an extension of this literature and is focused on relationships between rapeseed methyl ester (RAME) also named biodiesel, diesel oil and rapeseed prices. In these relationships, breaks are detected. This leads to find an appropriate approach to explain the price of biodiesel taking into account both the evolution of oil markets and rapeseed market and also environmental policy through the fuel blending policy. Hence, the present research enlarges that literature in focusing on the relationships between biodiesel, diesel and rapeseed prices.

So the present research is very complementary to previous publications in searching for a structural relationship between is biodiesel, diesel oil and rapeseed prices, taking into account the large fluctuations of the oil prices. 


\section{METHODOLOGY AND DATA}

In this section, the long-term relationships between biodiesel, rapeseed and gasoil prices are studied using econometric analysis of cointegration. The analysis is based on the time series of the different product prices. Since agricultural commodity markets for rapeseed and biodiesel are quoted in euros while oil and gasoil prices are quoted in US dollars, the euro/US dollar rate is also taken into account in the model. The analysis requires performing unit-root tests and cointegration tests. We show some breaks in the long-term relationship between the variables. Then, a Markov chain with changing regime is estimated.

The hypothesis to be tested is that there exists a long-term relationship between the price of biodiesel and the price of rapeseed resources and gasoil. It is assumed that oil distributors may adjust the content in biodiesel in the distributed oil according to costs and regulation rules such as compulsory blending of biodiesel into diesel, incentives and penalties.

The search for a long-term relationship between different variables was originally based on the use of the model from Engle and Granger (1987) when only a single relationship had to be tested. It was enlarged by Johansen (1988) in the multivariate case. Nevertheless, the standard Augmented DickeyFuller (1979) and Phillips-Perron (1988) tests (respectively denoted ADF and PP) on the residual values of the cointegration model and on the observed series, leading to non-rejection of a unit root, is difficult when the sample under consideration incorporates structural changes. Thus, the structural break detection successively carries out tests for unit root, first on the series and then on the cointegration models. The more general problem of estimating linear models with multiple structural changes, which concerns us more closely, was studied by Bai and Perron (1998, 2003a, b). These tests are synthetized in appendix A.1.

Monthly data are used from November 2006 when methyl ester of rapeseed oil, that is biodiesel, was quoted for the first time in Europe. The sample ends in January 2016 and consists of 111 observations. All prices are in euros per ton since major European oil refiners and biodiesel processors operate in the euro zone (France, Germany, etc.). Brent prices are converted from $\$ /$ barrel into $€ /$ t. The Platts dated Brent crude is chosen as an assessment of the price of physical light North Sea crude oil. The analysis therefore focuses on the four variables, quoted in $€ / t$ :

- PGDOE: price of gasoil, 10 ppm North West Europe destination Germany,

- PRapeseed: rapeseed price at the nearest maturity on the Euronext Paris futures market,

- PEster: methyl ester price rapeseed, that is biodiesel, destination Germany,

- PBrente: crude oil prices of North Sea (dated Brent) quoted in London.

These variables are plotted on figure 2 from November 2006 to January 2016. 
In our modeling, all prices are expressed in euros. However the Brent and the gasoil prices are quoted in US dollars. The comparison between the prices in euros (figure 2) and in dollars (figure 3 ) shows that the peak of all variables expressed in euros is in January 2011 while the peak of all variables expressed in US dollars is in July 2008. This will lead to taking into account the euro/US dollar parity in our modeling approach.

Figure 2 - Brent, rapeseed, ester (biodiesel) and Figure 3 - Brent, rapeseed, ester (biodiesel) and gasoil prices in Europe, in euro/ton

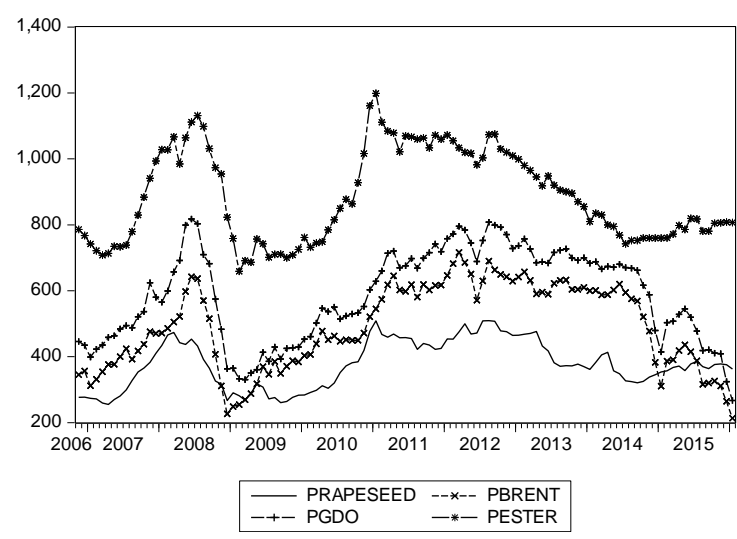

Unit: $€ / \mathrm{t}$

Source: Argus, Platts, Euronext gasoil prices in Europe, in dollar/ton

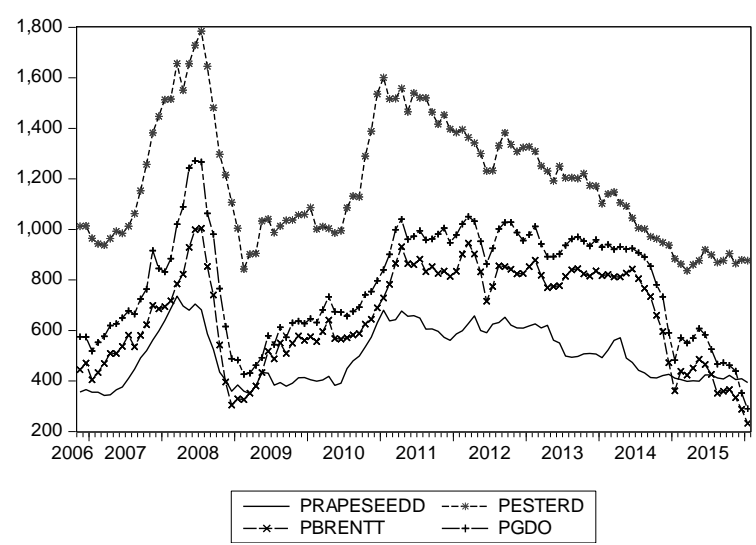

Unit: $\$ / \mathrm{t}$

Source: Argus, Platts, Euronext

Furthermore, oil distributors buy gasoil and biodiesel to produce and sell diesel in conformity with environmental regulations on biodiesel blending. Facing oil and ester prices, they decide upon the blending level according to spread prices between biodiesel and diesel prices. As shown in figure 4, the spread declined sharply in late 2011 and only increased again in the late months of 2015.

Figure 4 - Spread between ester and gasoil prices

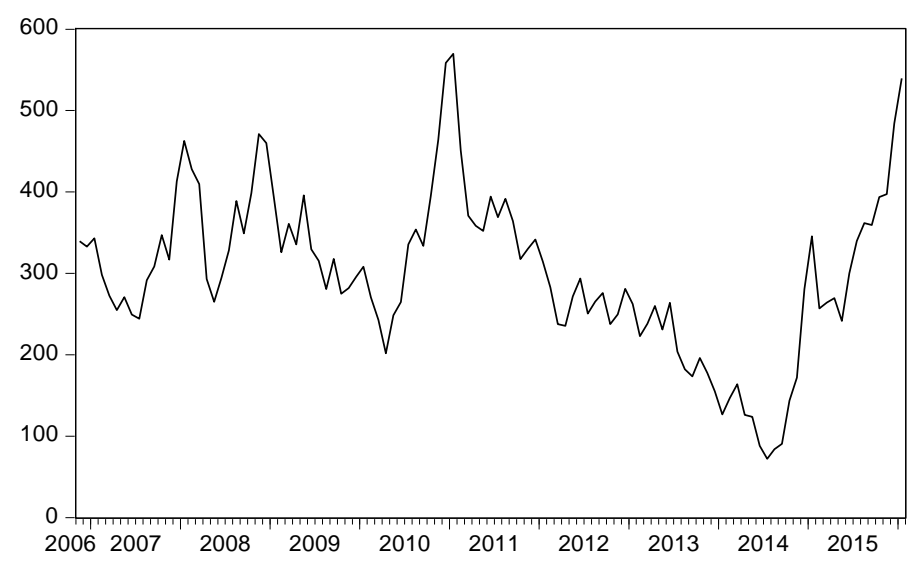

Unit : $€ / \mathrm{t}$

Source: Argus, Platts, Euronext 
The potential relationships between the prices are tested with the prices in logarithm terms. First, the stationarity of the data series is tested. Then, structural break tests presented before are performed and finally a Markov chain model between biodiesel, rapeseed oil and diesel prices is estimated.

\section{EMPIRICAL RESULTS}

The results concern the econometric analysis of the relationship between ester (biofuel), rapeseed and diesel prices. The section focuses on structural breaks within the series and the relationships between them. Test for stationarity of the data series with several unit-root tests, including the ADF and PP tests and the Zivot and Andrews (1992) test are summarized in appendix A.2. Moreover, a cointegration analysis was performed between ester gasoil and rapeseed oil prices on the European market. The test shows that no cointegration was found over the entire period from November 2006 to January 2016. However, significant results were obtained when the test was performed on a subsample from November 2006 to December 2009, before the rise of ester and rapeseed oil prices in 2010.

The sequential test Bai and Perron shows multiple break points which are discussed. A Markov chain model with changing regime is estimated. The probability of being in each regime is determined according to oil price levels.

\subsection{Test of multiple breaks in the price relationship between ester, rapeseed and gasoil}

The existence of multiple breaks in the relationship between $\ln$ (Pester), $\ln$ (Prapeseed) and $\ln$ (Pgdoe) is tested in using several tests proposed by Bai-Perron which are described above. Thus, we assess the following model:

$$
\begin{aligned}
& \ln \left(\text { pester }_{t}\right)=\delta_{0, j}+\delta_{1, j} \ln \left(\text { prapeseed }_{t}\right)+\delta_{2, j} \ln \left(\text { pgdo }_{t}\right)+u_{t}, \\
& t=T_{j-1}+1, \ldots, T_{j} \text { for } j=1, \ldots, m+1
\end{aligned}
$$

We carry out the sequential test $l+1 / l$, the sequential test all subsets, the test global $l$ versus none, the test $l+1$ versus $l$ globally determined, the structural break test based on the Schwarz Information and Liu, Wu and Zidel (LWZ) criterion and finally the tests based on a fixed number of structural break dates. Tests are performed with the Eviews 11 software. In this paragraph, we focus on the results of the test $l+1 / l$ and the test $l+1$ versus $l$ globally determined.

Tables 2, 3 and 4 show the results of the three types of Bai-Perron tests. The five tests detect common break dates in March 2012 and January 2014, matching strong falls in the price difference between biodiesel and gasoil as shown in figure 4 . The refining oil into gasoil results in a significant gross margin. 
The test $l+1 / l$ Three breaks are found to be significant as shown in table 3. By decreasing order of significance, the three breaks are found in March 2012, January 2014 and January 2009 since the statistic $F_{T}(l+1 / l)$ is greater than the threshold value at a $5 \%$ risk. Each of these dates matches some important oil or gasoil diesel price movement: the end of the oil price increase in March 2012, the strong decrease in gasoil diesel prices in January 2009 and the end of high oil prices in January 2014.

The next detected break dates are March 2008 and July 2009, at times of high oil price increases as shown in figures 2 and 3. When a fifth break date is found, it is in November 2010 at time of high biodiesel and gasoil price differential in winter. Profit margin seems a major criterion to explain breaks.

Tests that do not use the heteroscedasticity and autocorrelation consistent (HAC) estimator also identify March 2009 as a break date. It is also found using the Zivot and Andrews test applied to a model with a constant and a trend. From an economic viewpoint, March 2009 is characterized by a strong decrease in oil price.

Table 2 - Bai-Perron break tests (HAC co-variances, allowing heterogeneous error distribution across breaks in all sub-periods)

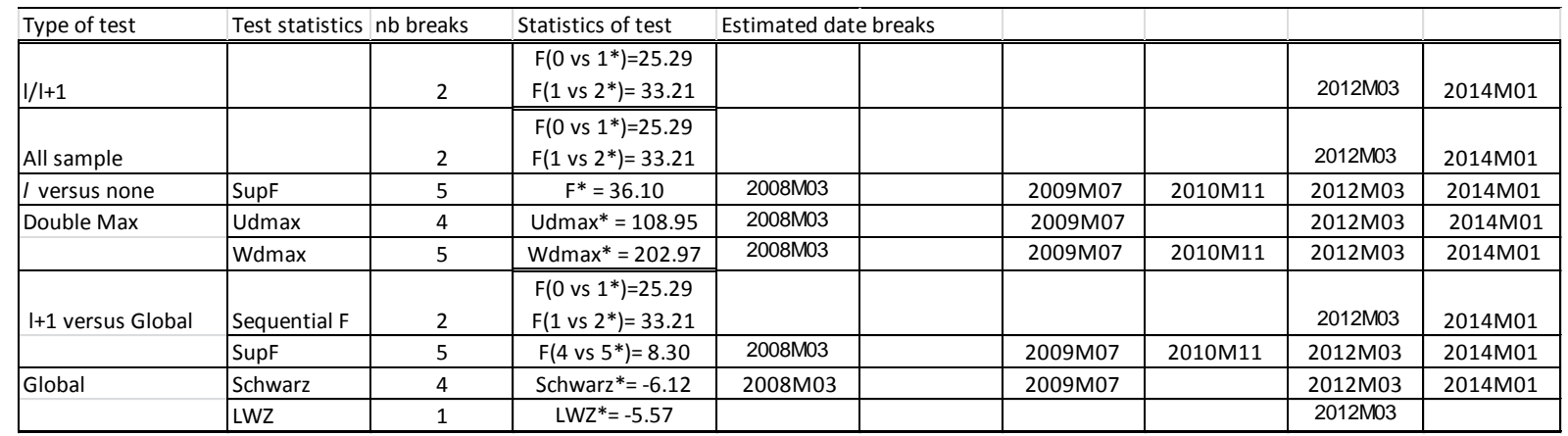

Table 3 - Bai-Perron break tests (HAC co-variances, assuming common data distribution in the sub-periods)

\begin{tabular}{|c|c|c|c|c|c|c|c|c|}
\hline Type of test & Test statistics & nb breaks & & Estimated da & & & & \\
\hline$|/|+1$ & & 2 & $\begin{array}{l}F\left(0 \text { vs } 1^{*}\right)=25.37 \\
F\left(1 \text { vs } 2^{*}\right)=31.83\end{array}$ & & & & 2012M03 & 2014M01 \\
\hline All sample & & 2 & $\begin{array}{l}F\left(0 \text { vs } 1^{*}\right)=25.37 \\
F\left(1 \text { vs } 2^{*}\right)=31.83\end{array}$ & & & & 2012M03 & 2014M01 \\
\hline I versus none & SupF & 5 & $F^{*}=135.69$ & 2008M03 & 2009M07 & $2010 \mathrm{M} 11$ & $2012 \mathrm{M03}$ & 2014M01 \\
\hline \multirow[t]{2}{*}{ Double Max } & Udmax & 5 & Udmax* $=135.69$ & 2008M03 & 2009M07 & $2010 \mathrm{M} 11$ & 2012M03 & $2014 \mathrm{M} 01$ \\
\hline & Wdmax & 5 & Wdmax ${ }^{*}=254.29$ & 2008M03 & 2009M07 & $2010 \mathrm{M} 11$ & 2012M03 & 2014M01 \\
\hline \multirow[t]{2}{*}{ I+1 versus Global } & Sequential F & 2 & $\begin{array}{l}F\left(0 \text { vs } 1^{*}\right)=25.37 \\
F\left(1 \text { vs } 2^{*}\right)=31.83\end{array}$ & & & & 2012M03 & 2014M01 \\
\hline & SupF & 5 & $F\left(4\right.$ vs $\left.5^{*}\right)=14.56$ & 2008M03 & 2009M07 & $2010 \mathrm{M} 11$ & 2012M03 & 2014M01 \\
\hline \multirow[t]{2}{*}{ Global } & Schwarz & 4 & Schwarz $*=-6.12$ & $2008 \mathrm{M03}$ & 2009M07 & & $2012 \mathrm{M03}$ & 2014M01 \\
\hline & LWZ & 1 & $L W Z^{*}=-5.57$ & & & & 2012M03 & \\
\hline
\end{tabular}


Table 4 - Bai-Perron break tests (assuming common data distribution in the sub-periods)

\begin{tabular}{|c|c|c|c|c|c|c|c|c|}
\hline \multirow[t]{2}{*}{ Type of test } & \multirow[t]{2}{*}{ Test statistics } & \multirow{2}{*}{$\begin{array}{c}\text { nb breaks } \\
\\
3\end{array}$} & \multicolumn{3}{|c|}{ Estimated date breaks } & & \multirow[b]{2}{*}{ 2012M03 } & \multirow[b]{2}{*}{$2014 \mathrm{M} 01$} \\
\hline & & & $\begin{array}{l}F\left(0 \text { vs } 1^{*}\right)=47.69 \\
F\left(1 \text { vs } 2^{*}\right)=8.57 \\
F\left(2 \text { vs } 3^{*}\right)=7.12 \\
\end{array}$ & & 2009M02 & & & \\
\hline All sample & & 3 & $\begin{array}{l}F\left(0 \text { vs } 1^{*}\right)=47.69 \\
F\left(1 \text { vs } 2^{*}\right)=5.61 \\
F\left(1 \text { vs } 2^{*}\right)=8.57\end{array}$ & & 2009M02 & & 2012M03 & 2014M01 \\
\hline I versus none & SupF & 3 & $\mathrm{~F}^{*}=28.93$ & $2008 \mathrm{M} 03$ & & 2009M07 & $2012 \mathrm{M} 03$ & \\
\hline \multirow[t]{2}{*}{ Double Max } & Udmax & 1 & Udmax $* 143.08$ & & & & $2012 \mathrm{M} 03$ & \\
\hline & Wdmax & 1 & Wdmax $^{*}=143.08$ & & & & 2012M03 & \\
\hline \multirow[t]{2}{*}{ I+1 versus Global } & Sequential F & 4 & $\begin{array}{l}F\left(0 \text { vs } 1^{*}\right)=47.49 \\
F\left(1 \text { vs } 2^{*}\right)=8.57 \\
F\left(2 \text { vs } 3^{*}\right)=7.12 \\
F\left(3 \text { vs } 4^{*}\right)=14.34\end{array}$ & 2008M03 & & 2009M07 & $2012 \mathrm{M} 03$ & 2014M01 \\
\hline & SupF & 4 & $F\left(3\right.$ vs $\left.4^{*}\right)=14.34$ & $2008 \mathrm{M} 03$ & & 2009M07 & 2012M03 & $2014 \mathrm{M} 01$ \\
\hline \multirow[t]{2}{*}{ Global } & Schwarz & 4 & Schwarz $^{*}=-6.12$ & $2008 \mathrm{M} 03$ & & 2009M07 & $2012 \mathrm{M} 03$ & $2014 \mathrm{M} 01$ \\
\hline & LWZ & 1 & LWZ* $=-5.57$ & & & & 2012M03 & \\
\hline
\end{tabular}

Finally, we consider the estimations over $m+1=6$ sub-samples following the Udmax test. They indicate that the impact of rapeseed and diesel prices are different according to the breakpoints (table 4). When oil prices strongly fluctuated from $2008 \mathrm{~m} 03$ to $2009 \mathrm{~m} 06$, biodiesel prices were mainly driven by diesel prices. Because biodiesel blending is compulsory, the impact of diesel prices remained significant from $2012 \mathrm{~m} 3$ to $2013 \mathrm{~m} 12$ when rapeseed prices decreased whilst oil prices were still high. Rapeseed price elasticity is around 0.65 from $2006 \mathrm{~m} 11$ to $2008 \mathrm{~m} 02$ and from $2009 \mathrm{~m} 07$ to $2012 \mathrm{~m} 02$ which highlights the role of resources prices over these periods. This influence fell after March 2012: this could be explained by the increasing imports of biodiesel from outside the EU.

Table 5 - Least-squares estimation of the relationship between biodiesel, diesel and ester prices

\begin{tabular}{|l|l|l|l|}
\hline period & intercept & $\ln$ (prapeseed) & $\ln$ (pgdoe) \\
\hline $2006 \mathrm{~m} 11-2008 \mathrm{~m} 02$ & $2.92142 * * *$ & $0.657607 * * *$ & -0.001895 \\
\hline $2008 \mathrm{~m} 03-2009 \mathrm{~m} 06$ & $3.928522 * * *$ & -0.16571 & $0.614149 * * *$ \\
\hline $2009 \mathrm{~m} 07-2010 \mathrm{~m} 10$ & $2.806032 * * *$ & $0.664151 * * *$ & 0.00633 \\
\hline $2010 \mathrm{~m} 11-2012 \mathrm{~m} 02$ & $3.573666 * * *$ & $0.620164 * * *$ & -0.058632 \\
\hline $2012 \mathrm{~m} 03-2013 \mathrm{~m} 12$ & $1.573766 * * *$ & $0.375189 * * *$ & $0.456877 * * *$ \\
\hline $2014 \mathrm{~m} 01-2016 \mathrm{~m} 01$ & $4.135337 * * *$ & $0.429557 * * *$ & 0.00035 \\
\hline
\end{tabular}

Note: $* * *$ significant at the threshold of $1 \%, * * 5 \%, * 10 \%$.

\subsection{Markov chain model with switching regime}

Since break tests lead to finding several structural changes matching very strong price movements, it seems that high oil or gasoil diesel prices drive ester prices and it seems that low oil or gasoil diesel prices do not have the same impact on ester prices. So a Markov chain model is tested with two regimes explaining $\ln$ (pester) by $\ln$ (prapeseed) and $\ln$ (pgdoe). A detailed presentation of such switching model estimation is proposed by Hamilton (2005). A dummy variable is added for January 2009 (D2009M1), matching both low oil prices and the enforcement of new specifications on automotive fuels in the EU. 
The transition probability from one regime to another may be explained by oil prices $\ln$ (pbrente) and by the euro/US dollar parity, written as $\ln ($ eurusd).

The model estimation with Eviews provides the following results:

Regime 1: $\ln (\text { pester })_{t}=\underset{(0,299)}{4,212}+\underset{(0,094)}{0,309} \ln (\text { prapeseed })_{t}+\underset{(0,067)}{0,133 \ln }(\text { pgdoe })_{t}+\hat{\varepsilon}_{t}$

Regime 2: $\ln (\text { pester })_{t}=\underset{(0,142)}{3,218}+\underset{(0,034)}{0,488} \ln (\text { prapeseed })_{t}+\underset{(0,026)}{0,099 \ln }(\text { pgdoe })_{t}+\hat{\varepsilon}_{t}$

( ) standard deviation

The transition matrix $P_{t}$ between time $\mathrm{t}-1$ and time thas the following form:

$$
P_{t}=\left[\begin{array}{ll}
p_{11 t} & p_{12 t} \\
p_{21 t} & p_{22 t}
\end{array}\right]
$$

where $p_{i j}=p\left(E_{t}=j / E_{t-1}=i\right)$ is the transition probability of regime $\mathrm{i}$ at time $\mathrm{t}-1$ towards regime $\mathrm{j}$ at time t. The transition probabilities are explained using a multinomial logit model in function of a constant term and oil price at time $\mathrm{t}-1$. We get the estimation of probabilities, except for the probabilities linked to the last column of the matrix $P_{t}$. The probabilities $p_{11}$ and $p_{21}$ may be expressed as:

$$
\left\{\begin{array}{l}
p_{11 t}=\frac{1}{1+e^{-\left(-1,982 \ln \left(\mathrm{Pbrent}_{t}+51,534 \log (\operatorname{lourusd})_{t}\right)\right.}} \\
p_{21 t}=\frac{1}{1+e^{-(-1,887)}(0,444)\left(\ln \left(\mathrm{Pbrent}_{t}+24,227 \ln (\text { (eurusd })_{t}\right)\right.}
\end{array}\right.
$$

The probability of regime 1 is estimated over the period as shown in figure 5 (the unconditional probability of regime 2 is the complement of the unconditional probability of regime 1). Regime 1 is characterized by high oil prices in 2008 and over the period from the end of 2010 to spring 2012. 
Figure 5 - Unconditional probability of regime 1

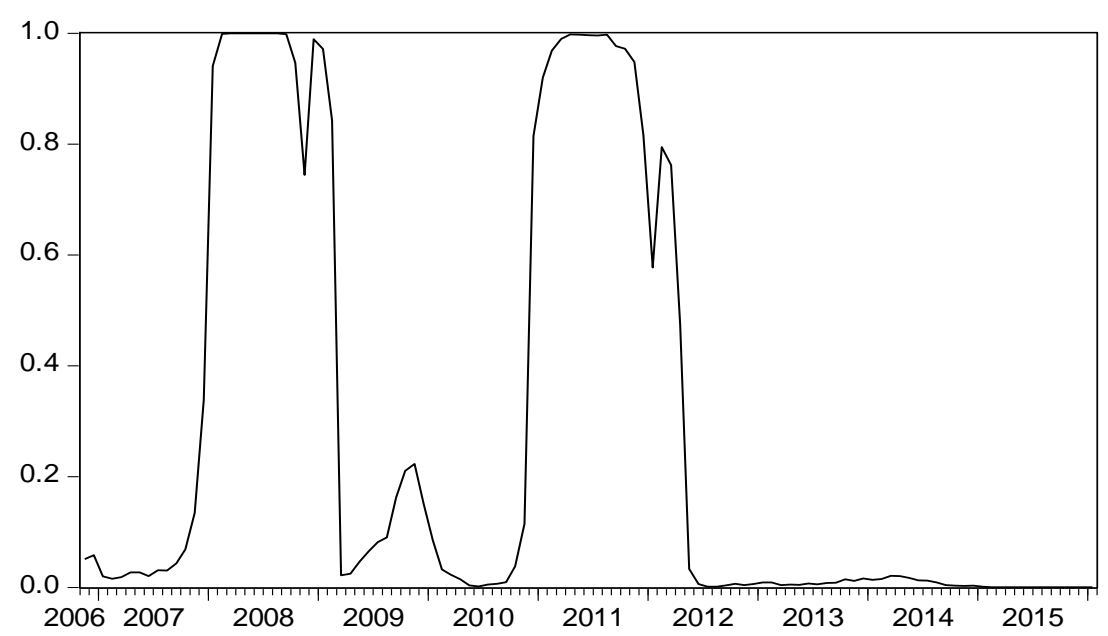

The econometric estimation of biodiesel prices results in a gasoil price coefficient of 0.133 in regime 1 and 0.099 in regime 2. So the gasoil price coefficient difference is 0.034 . The gasoil price coefficient is about $3.4 \%$ higher in regime 1 than in regime 2. It means that gasoil prices have a stronger impact on biodiesel prices in regime 1 when oil prices are high. Biodiesel price elasticity with respect to gasoil prices is $3.4 \%$ higher in regime 1 than in regime 2.

In contrast, the rapeseed price coefficient has a stronger impact on biodiesel prices in regime 2 since the coefficient is 0.309 in regime 1 and 0.488 in regime 2 . Biodiesel price elasticity with respect to rapeseed prices is $17.8 \%$ lower in regime 1 than in regime 2 . Hence, when oil prices are high, regime 1 prevails with biodiesel prices mainly impacted by gasoil prices than by rapeseed prices. And when oil prices are low, regime 2 prevails with biodiesel prices mainly impacted by rapeseed prices than by gasoil prices.

Finally, we assess the link between gasoil and ester prices. For this purpose, a Granger causality test is performed between the two series expressed in price first difference $\Delta \ln$ (pgdoe) and $\Delta \ln$ (pester). Two lags have been considered according to the BIC and the Hannan Quinn criteria. The Fisher statistics is significant for a $5 \%$ risk since $\mathrm{F}(2,103)=4.186>3.084$ as shown in table 6 . So, the test result allows accepting the alternative hypothesis that gasoil prices Granger-cause biodiesel prices in the sense of Granger without any feedback effect.

Table 6 - Granger causality test between gasoil and ester prices

\begin{tabular}{lcrl}
\hline \hline Null Hypothesis: & Obs & \multicolumn{2}{l}{ F-Statistic Prob. } \\
\hline \hline$\Delta \ln$ (pester) does not Granger-cause $\Delta \ln$ (pgdoe) & 108 & 0.03817 & 0.9626 \\
$\Delta \ln ($ pgdoe) does not Granger-cause $\Delta \ln$ (pester) & & 4.18660 & 0.0179 \\
\hline
\end{tabular}

Note: Number of lags for the Granger causality test $=2$ 


\section{DISCUSSION}

All the above econometric tests, unit root test with rupture, cointegration test with multiple breaks and Markov chain model, provide results leading to convergent explanations. They enable to distinguish five sub-periods (denoted phases) from 2006 to 2016.

In phase 1, from November 2006 to February 2007: the sub-period experienced the start of the biodiesel market with the introduction of biofuel quotes on Euronext.

Biodiesel production has increased as a result of EU directives, leading to blending targets and the system of reducing taxes on biofuels and penalties on fossil fuels. In the European Union, the required blending rate of biodiesel (measured in the amount of energy) increased from 2\% in 2006 to 3.8\% in 2008. Over the sub-period, the results of the Markov Chain model show that biodiesel prices are rather driven by renewable resource prices.

From an economic viewpoint, global economics is slightly booming, so oil demand is still low and oil price is low. So the demand for biodiesel is only bound by the "blend wall", that is the legal requirement of biodiesel blending into diesel. Consequently, biodiesel price is related mainly to its raw material price that is rapeseed price.

In phase 2, from March 2008 to June 2009: the sub-period was a phase of rise until July 2008 and then a sharp fall in the oil price. The rapeseed price fluctuated in the same direction but less marked: the oilseeds (soybean on CBOT and canola on the Winnipeg Futures market) markets were experiencing lower voltages than oil markets, with supply and food demand remaining more stable. Two tests, $(1 / 1+1)$ and "all sample" tests, (Table 3) signal a potential break in February 2009. This can be explained by the introduction new standards (10 ppm sulphur content) on automotive fuels in the EU and the increase in biofuel blending targets. Thus, it may explain the slight rebound in the Brent oil price and the rapeseed price. Nevertheless, this latter rupture is detected under the hypothesis of common variability over all sub-periods. It leads to not consider February 2009 as a structural break. From March 2008 to June 2009, biofuel price appears to be driven mainly by oil price.

From an economic viewpoint, demand for biodiesel was booming. The biodiesel "blend wall" was binding. This explains that the EU imports of biodiesel increased by $77 \%$ from 1,140 billion liters (that is 1.01 million tons) in 2007 to 2.02 billion liters (that is 1.71 million tons) in 2008 . Furthermore, higher demand for biodiesel was not only bound by the "blend wall". The EU imports of rapeseed increased 4.8 times from 685 thousand tons in 2007-2008 to 3,353 thousand tons in 2008-2009 as shown in table 1. Furthermore, exports went down over the same period.

However, higher demand for biodiesel might have involved anticipations of forthcoming higher blending rate of biodiesel in diesel for transportation, due to pressures from national governments on 
the EU Commission. The European governments wanted to improve their state commercial balance and national employment rate in blending more renewable energies coming from oilseeds (mainly rapeseed) produced locally. The EU was working on new EU directive to increase the blending rate of biofuels in order to pass the law on the following year as stated by the EU Renewable Energy Directive (RED1) 2009/28.

Consequently, EU biodiesel price departed from the economic rapeseed supply and demand equilibrium. Biodiesel price was higher and seemed drawn by the higher oil price.

In phase 3, from July 2009 to October 2010, the biodiesel price was driven mainly by the price of rapeseed over the sub-period. Rapeseed price was much higher than gasoil price (figure 4). This could be explained by the increasing blending targets up to $10 \%$ level in the EU by 2020 (Directive 2009/28/CE, April 2009) and euro/dollar exchange rate effect. The blending target was then reduced to $7 \%$ for biofuel from agricultural products.

From an economic viewpoint, global economics was stagnant, so oil demand was low and oil price was low. The EU economics was also stagnant. The EU imports of rapeseed went down from 3,353 thousand tons in 2008-2009 to 2,082 thousand tons in 2009-2010. The EU demand for biodiesel was only bound by the EU "blend wall", meaning the legal requirement of biodiesel blending in the diesel pool. Consequently, biodiesel price was related mainly to rapeseed price.

The EU Renewable Energy Directive (RED1) 2009/28 on renewable has been enforced in 2009. In terms of energy content, the objective was to increase from $5.75 \%$ to $7 \%$ the blending rate of biodiesel into diesel used for transportation.

In phase 4, from November 2010 and February 2012: the biodiesel price was more driven by the oil price over the sub-period. The period was marked by a sharp increase in the oil price, mainly linked to geopolitical tensions, including tensions in Libya, affecting oil markets.

From an economic viewpoint, global economics was booming strongly with very high oil demand and very high oil price. The EU biodiesel "blend wall" was binding. The EU imports of rapeseed went up from 2,082 thousand tons in 2009-2010 to 2,624 thousand tons in 2010-2011 and to 3,752 thousand tons in 2011-2012 as shown in table 1. Again, higher demand for biodiesel was bound not only the "blend wall" but may also involve anticipations of forthcoming increase in biodiesel blending due to pressures from national governments even though some NGO did not share governments views.

Consequently, EU biodiesel price departed from the economic rapeseed supply and demand equilibrium. EU biodiesel price was higher and seemed drawn by the higher oil price.

In phase 5, from March 2012 to January 2016: the biodiesel price was driven mainly by the rapeseed price over the sub-period. From an economic viewpoint the EU economics grew very slowly with low oil demand while world shale oil production increases so strongly that oil price was low. The evolution 
of EU rapeseed imports confirmed the low demand for diesel. The EU imports of rapeseed went down from 3,752 thousand tons in 2011-2012 to 3,378 thousand tons in 2012-2013 and even further down to 2,317 thousand tons in 2014-2015 as shown in table 1.

Hence the EU demand for biodiesel was only bound by the "blend wall". Consequently, biodiesel price was related mainly to rapeseed price.

In a microeconomic perspective expressed on figure 6 , the five sub-periods could be interpreted as follows.

In phases 1, 3 and 5, the biodiesel price is driven mainly by the price of rapeseed due to low oil demand. So the demand for biodiesel is only bound by the "blend wall". Consequently, biodiesel price is related mainly to its raw material price that is rapeseed price (named "Regime 2" on figure 6).

In phases 2 and 4, global economics is booming strongly with very high oil demand and very high oil price. higher demand for biodiesel is bound not only the "blend wall" but may also involve anticipations of forthcoming increase in biodiesel blending due to pressures from national governments even though some NGO do not share governments views.

Consequently, EU biodiesel price departs from the economic rapeseed supply and demand equilibrium. EU biodiesel price is higher and seems drawn by the higher oil price (named "Regime 1" on figure 6). 
Figure 6: Demand for biodiesel, rapeseed and oil

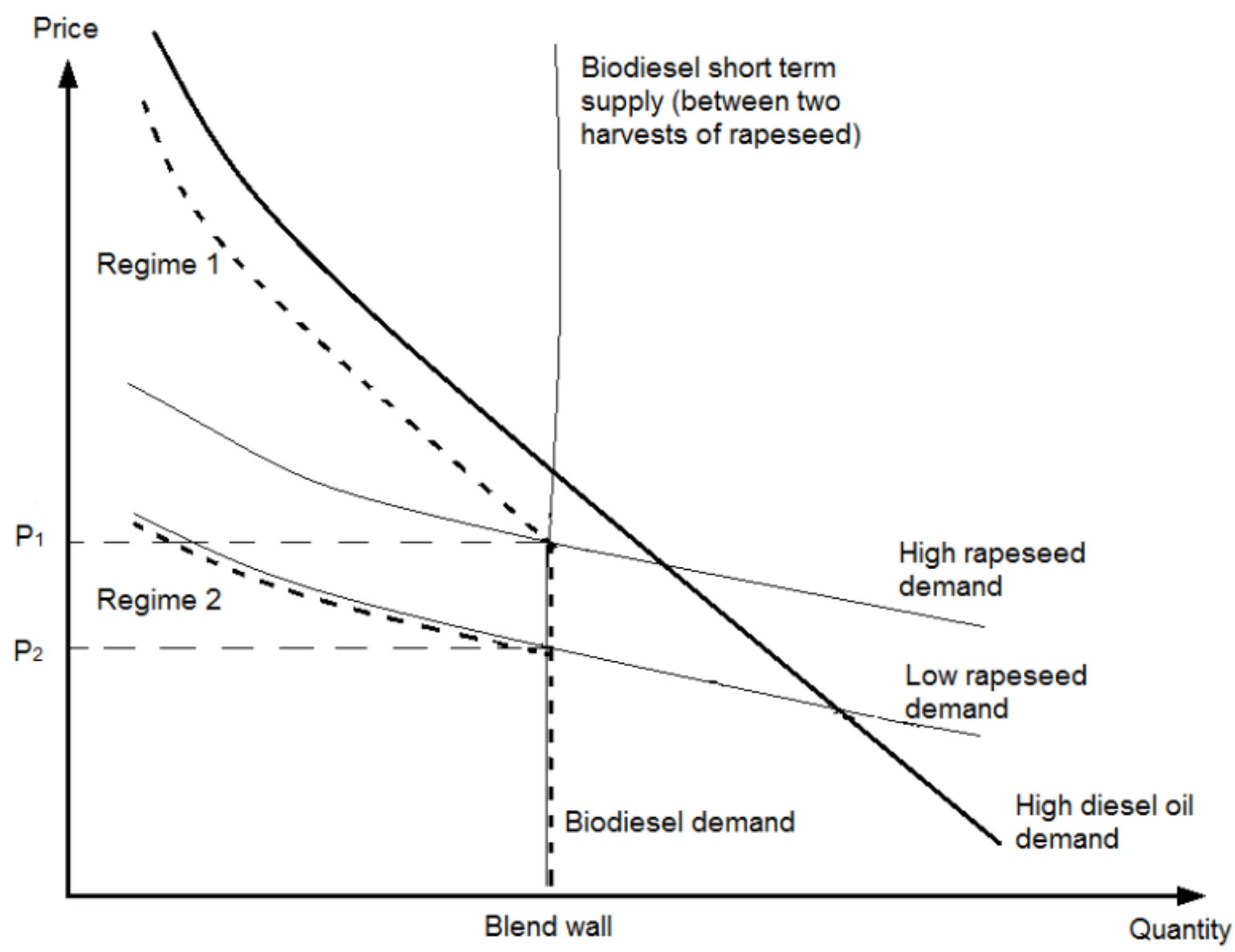

\section{CONCLUSION}

This paper aims at identifying the major drivers of biodiesel prices in Europe while biodiesel production has expanded since the enforcement of the 2003 EU Directive on environmental policy for automotive fuels in 2006. In 2009, the EU Renewable Energy Directive was modified in stating new constraining targets of biodiesel blending in the diesel up to the year 2020 revised later on.

The paper shows that biodiesel prices in Europe are explained by the price of agricultural commodity resources and the price of gasoil used for automotive fuels.

Using monthly data from November 2006 to January 2016, the results of the performed tests do not enable finding any cointegration over the entire period. However, the Bai and Perron tests for structural change in the long-term relationship between biodiesel and diesel prices enable finding three major breakpoints involving changing regime in January 2009, March 2012 and January 2014.

The search for long-term relationships between different variables is based on the cointegration techniques suggested by Johansen (1988). The break tests revealed several structural changes 
corresponding to upward or downward swings in different prices. A Markov chain model was estimated with two regimes explaining ester prices through rapeseed oil and gas diesel oil prices. Transition from one regime to another might be explained by the evolution of diesel prices. It enables finding cointegration with two different regimes:

- a regime with the price of ester (that is biofuel) driven mainly by gasoil prices in times of high gasoil and oil prices: 2006-2007, 2010-November 2012, so the ester price is also related to gasoil prices according to such a relationship,

- a regime with the price of ester driven mainly by rapeseed prices in times of low gasoil and oil prices: the year 2009, December 2012-2014. Such new dynamics may be due to the annual harvest of agricultural oilseeds leading to short-term price inelasticity of production and EU targets for the oilseed derivatives blending into fuels through tax incentives.

The biodiesel price is therefore mainly related $1 /$ to rapeseed prices which are very inelastic since harvest only occurs once a year, 2/ to the market prices of edible oils (rapeseed, soybean, palm, etc.) which are used for food usage, and $3 /$ to the strong incentive to incorporate esters into gasoil to avoid tax on polluting activities in Europe.

After drops in oil prices, the biodiesel and the rapeseed prices seem no longer in the same long-term relationship with gas diesel oil prices. Oil product taxes in EU countries are high enough to create a strong incentive for fuel processors-distributors to blend biofuels with petroleum fuels. Hence, biodiesel prices are balanced between resource (rapeseed) prices and gasoil automotive fuel prices. 


\section{References:}

Andrews D. W.K. (1993). "Test for parameter instability and structural change with unknown change point." Econometrica 61, 821-856.

Bai J., Perron P. (1998). "Estimating and testing linear models with multiple structural changes." Econometrica 66, 47-78.

Bai J., Perron P. (2003a). "Computation and analysis of multiple structural change models." Journal of Applied Econometrics 18, 1-22.

Bai J., Perron P. (2003b). “Critical values for multiple structural change tests.” Econometrics Journal 6, 72-78

Balke, N.S., Fomby, T.B. (1997). “Threshold cointegration.” International Economic Review 38, 627645.

Barnard J., (1983). "Gasohol/ethanol: a review of national and regional policy and feasibility issues." Regional Science Perspectives 13, 3-14.

Britz W., Hertel T. (2011). "Impacts of EU biofuels directives on global markets and EU environmental quality: An integrated PE, global CGE analysis.” Agriculture, Ecosystems \& Environment 142, $102-$ 109.

Campiche, J.L., Bryant H.L., Richardson J.W., Outlaw, J.L. (2007). "Examining the Evolving Correspondence Between Petroleum Prices and Agricultural Commodity Prices." Research in agricultural and applied economics $15 \mathrm{p}$.

Carriquiry, M., Dong, F., Du X., Elobeid, A., Fabiosa, J. F., Chavez, E., and Pan, S. (2010). "World market impacts of high biofuel use in the European Union.” Technical Report Working Paper 10WP 508, Center for Agricultural and Rural Development, Iowa State University, Ames, Iowa.

Ciaian P., K. D'Artis (2011). "Interdependencies in the energy-bioenergy-food price systems: A cointegration analysis." Resource and Energy Economics 33, 326-348.

Dickey D., Fuller W.(1979). "Distribution of the estimators for autoregressive time series with a unit root." Journal of the American Statistical Association 74 (366), 427-431.

Engle R., Granger W.(1987). "Cointegration and error correction: representation, estimation and testing." Econometrica 55(2), 252-276.

Filip O., Janda K., Kristoufek L., Zilberman D. (2017). "Food versus fuel : an updated and expanded evidence.” https://doi.org/10.1016/j.eneco.2017.10.033

Hamilton J., D. (2005). "Regime-Switching Models.” In Palgrave Dictionary of Economics. Springer Ed. 16 p. http://econweb.ucsd.edu/ jhamilto/palgrav1.pdf (accessed 07.09.2017)

Harri, A., Nalley, L., Hudson, D., (2009). "The Relationship between oil, exchange rates, and commodity prices." Journal of Agricultural and Applied Economics 41 (2), 501-510.

Hertel, T., Beckman, J. (2011). "Commodity price volatility in the biofuel era: an examination of the linkage between energy and agricultural markets." NBER Working Paper ${ }^{\circ} 16824,51$ p. http://www.nber.org/papers/w16824.pdf (accessed 07.09.2017) 
Johansen S., (1988). "Statistical analysis of cointegration vectors." Journal of Economic Dynamics and Control 12(2-3): 232-254.

Liu J., Wu S., Zidel J (1997). “On segmented multivariate regression.” Statistica Sinica 7, 497-525.

Natanelov V., (2014). "Commodity futures markets: dynamic interrelationships between financial asset markets, energy markets and traditional agricultural commodity markets.” Ph.D. thesis, Gent University.

Natanelov V., M.J. Alam, A.M. McKenzie, G. van Huylenbroeck, (2011). "Is there co-movement of agricultural commodities futures prices and crude oil? “ Energy Policy 39, 4971-4984.

Padula A.D., Santos M.S., Ferreira L., Borenstein D. (2012). "The emergence of the biodiesel industry in Brazil : Current figures and future prospects.” Energy Policy 44, 395-405.

Peñaranda F., Rupérez Micola A., (2011). "The Emergence of Biofuels and the Co-Movement between Crude Oil and Agricultural Prices.” Department of Economics and Business, Pompeu Fabra University. Economic working paper $n^{\circ} 1174,42$ p., https://econ-papers.upf.edu/papers/1174.pdf (accessed 07.09.2017)

Peri, M., Baldi, L. (2010). "Vegetable oil market and biofuel policy: an asymmetric cointegration approach.” Energy Economic 32 (3), 687-693.

Perron P. (2006). "Dealing with structural breaks.” Palgrave Handbook of Econometrics.

Phillips P., Perron P.(1988). “Testing for a unit root in time series regression.” Biometrika, 75, 335346.

Sorda G., Banse M., Kenfert M. (2010). “An overview of biodiesel policies across the world.” Energy Policy 38, 6977-6988.

Tyner W., (2010). “The integration of energy and agricultural markets.” Agricultural Economics 41, 193-201.

Yao, Y. C. (1988). "Estimating the Number of Change-points via Schwarz' Criterion..” Statistics and Probability Letters 6, 181-189.

Zhang, Y.J., Lohr L, Escalante C., Wetzstein M. (2010). „Food versus fuel: What does price tell us?” Energy Policy 38 (3), 1445-451

Zivot E., Andrews D (1992). "Further evidence on the great crash, the oil price shock and the unit root test hypothesis." Journal of Business and Economic Statistics 10, July, 251-270 


\section{APPENDIX}

\section{A.1. Tests for multiple structural breaks in the cointegration relationship}

In the framework of a multiple regression model, Bai and Perron (1998, 2003a, b), denoted BP, suggest detecting multiple structural changes and to estimate break dates that are unknown. A general review of literature on structural break is proposed by Perron (2006). In its general version, the Bai-Perron process enables to identify structural regime changes and estimate break dates that are common to a sub-set of regressors.

The starting point for the analysis is a multiple linear regression with $\mathrm{T}$ observations and $\mathrm{m}$ potential breaks which involves $m+1$ regimes:

$$
y_{t}=x_{t}^{\prime} \beta+z_{t}^{\prime} \delta_{j}+u_{t}, \quad t=T_{j-1}+1, \ldots, T_{j}
$$

for $\mathrm{j}=1, \ldots, \mathrm{m}+1$. In this model, $\mathrm{y}_{\mathrm{t}}$ is the dependent variable at time $\mathrm{t}$, both $\mathrm{x}_{\mathrm{t}}(\mathrm{p} \times 1)$ and $\mathrm{z}_{\mathrm{t}}(\mathrm{q} \times 1)$ are vectors of regressors at time t. $\beta$ and $\delta_{\mathrm{j}}(\mathrm{j}=1, \ldots, \mathrm{m}+1)$ are the corresponding vectors of coefficients; $\mathrm{u}_{\mathrm{t}}$, the disturbance at time $\mathrm{t}$ can be no iid. Note that the regressors are divided into two groups. The $\mathrm{x}$ variables are those whose parameters do not vary across regimes, while the $\mathrm{z}$ variables have coefficients that are regime specific.

When all the parameters of the regression can change $(\mathrm{p}=0)$, this model is denoted 'pure structural change model' by BP.

The structural break dates or break points $\left(\mathrm{T}_{1}, \cdots, \mathrm{T}_{m}\right)$ are unknown and in line with BP, we have adopted the convention that $\mathrm{T}_{0}=0$ and $\mathrm{T}_{\mathrm{m}+1}=\mathrm{T}$.

The purpose is to estimate the unknown regression coefficients together with the break points in the sample of T observations.

The estimation method considered by BP is based on the OLS technique: for each m-partition $\left(\mathrm{T}_{1}, \cdots, \mathrm{T}_{m}\right)$, the OLS estimation of $\beta$ and $\delta_{i}(\mathrm{i}=1, \cdots, \mathrm{m})$ is obtained by minimizing the sum of squared residuals:

$$
S_{T}\left(T_{1}, \ldots, T_{m}\right)=\sum_{i=1}^{m+1} \sum_{t=T_{i-1}+1}^{T_{i}}\left(y_{t}-x_{t}^{\prime} \beta-z_{t}^{\prime} \delta_{i}\right)^{2}
$$


The OLS estimation of $\beta$ and $\delta_{i}$ using the m-partition $\left(\mathrm{T}_{1}, \ldots, \mathrm{T}_{\mathrm{m}}\right)$ are denoted $\hat{\beta}\left(\left\{\mathrm{T}_{\mathrm{i}}\right\}\right)$ and $\hat{\delta}\left(\left\{\mathrm{T}_{\mathrm{i}}\right\}\right)$. Substituting $\beta$ and $\delta_{i}$ by $\hat{\beta}$ and $\hat{\delta}_{i}$ in $\mathrm{S}_{\mathrm{T}}\left(\mathrm{T}_{1}, \ldots, \mathrm{T}_{\mathrm{m}}\right)$, the estimated break points $\left(\hat{\mathrm{T}}_{1}, \cdots, \hat{\mathrm{T}}_{m}\right)$ are derived from :

$$
\left(\hat{T}_{1}, \ldots, \hat{T}_{m}\right)=\underset{\left(T_{1}, \ldots, T_{m}\right)}{\arg \min } S_{T}\left(T_{1}, \ldots, T_{m}\right)
$$

where the minimization is performed on all the possible partitions. The search of the possible dates is restricted by introducing a minimum number of observations in each segment $\left(T_{i}, T_{i+1}\right)$. This is defined through a trimming parameter $\varepsilon$ (generally $\varepsilon=0.15)$. Denoting $\lambda_{\mathrm{i}}=\mathrm{T}_{\mathrm{i}} / \mathrm{T},(\mathrm{i}=1, \ldots, \mathrm{m})$ such as $\mathrm{T}_{i+1}-\mathrm{T}_{i}>\mathrm{T} \varepsilon$, the $\Lambda_{\varepsilon}$ set is defined by $\Lambda_{\varepsilon}=\left\{\left(\lambda_{1}, \ldots, \lambda_{\mathrm{m}}\right): \mid \lambda_{\mathrm{i}+1}-\lambda_{\mathrm{i}}>\varepsilon, \lambda_{1}>\varepsilon, \lambda_{\mathrm{m}}<1-\varepsilon\right\}$ and the estimated break points $\left(\hat{\mathrm{T}}_{1}, \cdots, \hat{\mathrm{T}}_{m}\right)$ are given by:

$$
\left(\hat{T}_{1}, \cdots, \hat{T}_{m}\right)=\underset{\left(\lambda_{1}, \cdots, \lambda_{m}\right) \in \Lambda_{\varepsilon}}{\arg \min } S_{T}\left(T_{1}, \cdots, T_{m}\right)
$$

A practical algorithm for computing global minimization based on the principle of dynamic programming is proposed by BP (2003a).

\section{Testing for the existence of breaks}

The statistics proposed by BP for multiple breaks are generalizations of the Andrews (1993) test for the single structural change using the maximal value of F-statistics (or Wald statistic). The BP tests are robust to serial correlation of the error terms and to heteroscedasticity of the error terms.

Test 1: No structural break versus a fixed number of breaks

BP propose a sup- $F$ type test to test the null hypothesis of $m=0$ break versus some arbitrary number of breaks, $\mathrm{m}=\mathrm{k}$. They built an $F$-test in the following manner, where break dates $\left(\mathrm{T}_{1}, \cdots, \mathrm{T}_{\mathrm{k}}\right)$ are not investigated directly, but indirectly using the fraction $\lambda_{\mathrm{i}}=\mathrm{T}_{\mathrm{i}} / \mathrm{T}, \mathrm{i}=1,2, \ldots, \mathrm{k}$ :

$$
F_{T}\left(\lambda_{1}, \ldots, \lambda_{k} ; q\right)=\frac{1}{T}\left(\frac{T-(k+1) q-p}{k q}\right) \hat{\delta}^{\prime} R^{\prime}\left(R \hat{V}(\hat{\delta}) R^{\prime}\right)^{-1} R \hat{\delta}
$$

where $\mathrm{R}$ is the matrix that allows $(\mathrm{R} \delta)^{\prime}=\delta_{1}^{\prime}-\delta_{2}^{\prime}, \ldots, \delta_{\mathrm{k}}^{\prime}-\delta_{\mathrm{k}+1}^{\prime}$. 
Furthermore, $\hat{\mathrm{V}}(\hat{\delta})$ is an estimator of the variance covariance matrix of $\hat{\delta}$ that is robust to serial and or heteroscedasticity (HAC estimator).

Following Andrews (1993), the sup- $F$ statistics is defined as follows:

$$
\sup _{T} F(k ; q)=\sup _{\left(\lambda_{1}, \ldots, \lambda_{k}\right) \in \wedge_{\varepsilon}} F_{T}\left(\lambda_{1}, \ldots, \lambda_{k} ; q\right)
$$

We can show that

$$
\sup \underset{T}{F}(k ; q)=F_{T}\left(\hat{\lambda}_{1}, \ldots, \hat{\lambda}_{k} ; q\right)
$$

where $\left(\hat{\lambda}_{1}, \ldots, \hat{\lambda}_{\mathrm{k}}\right)$ minimize the global residuals sum under the specified trimming $\varepsilon$.

The asymptotic critical values of sup $F_{T}$ depends on both the number of structural breaks $\mathrm{k}$, the $\mathrm{q}$ variables have coefficients that are regime specific and the trimming $\varepsilon$. These critical values were obtained by simulation (BP 1998, 2003 b).

\section{Test 2: Double maximum tests}

The number of breaks has to be fixed in the previous test. Thus, BP suggest two versions of the null hypothesis (no structural break) against the alternative hypothesis (the number of breaks $m$ is unknown) to endogenously determine the number of breaks. An upper bound of M breaks is specified to carry out the test. This test is named 'double maximum' because it uses the maximum of a sup expression. Two versions of the test are defined considering either an equal-weight for the $F$-statistics or a weight for each of them. The equal-weighted version of the test, UDmax is given by:

$$
U D \max \underset{T}{F}(M, q)=\max _{1 \leq m \leq M} \sup _{\left(\lambda_{1}, \ldots, \lambda_{m}\right) \in \wedge_{\varepsilon}} F_{T}\left(\lambda_{1}, \ldots, \lambda_{m} ; q\right)
$$

An alternative approach, denoted WDmax, applies weights to the individual statistics. This version can be expressed as follows:

$$
\begin{aligned}
W D \max \underset{T}{F}(M, q) & =\max _{1 \leq m \leq M} a_{m} \sup _{\left(\lambda_{1}, \ldots, \lambda_{m}\right) \in \wedge_{\varepsilon}} F_{T}\left(\lambda_{1}, \ldots, \lambda_{m} ; q\right) \\
& =\max _{1 \leq m \leq M} a_{m} F_{T}\left(\hat{\lambda}_{1}, \ldots, \hat{\lambda}_{m} ; q\right)
\end{aligned}
$$

When the weights $\mathrm{a}_{1}, \ldots \mathrm{a}_{\mathrm{M}}$ are defined as $\mathrm{a}_{1}=1$ and for $1 \leq m \leq M$ such as $\mathrm{a}_{\mathrm{m}}=\mathrm{c}(\mathrm{q}, \alpha, 1) / \mathrm{c}(\mathrm{q}, \alpha, \mathrm{m})$ where $\mathrm{c}(\mathrm{q}, \alpha, \mathrm{m})$ represents the asymptotic critical value of the test $F_{T}\left(\hat{\lambda}_{1}, \ldots, \hat{\lambda}_{\mathrm{m}} ; \mathrm{q}\right)$ for an arbitrary level of significance $\alpha$ and for m breaks (see BP (1998) for more details). 
Test 3: The test of $l$ against $l+1$ structural breaks

In a third test procedure, Bai and Perron investigate the relevance of an $l+1$ the structural break, knowing that $l$ breaks have already been considered. This test is based on $\sup F_{T}(l+1 / l)$.

Furthermore, the number of breaks can be specified by using the Bayesian Information Criterion (BIC) suggested by Yao (1988) or a modified criterion derived from the Schwarz criterion. Liu, Wu and Zidel (1997) propose a modified Schwarz criterion (denoted LWZ). This process consists in minimizing the LWZ criterion to get the number of breakpoints $m \geq 1$. So it tests whether there exists only one break and, if so, it tests the existence of a possible second one, and so forth.

\section{A.2 Tests for the stationarity of oil, rapeseed and biodiesel prices}

Unit-root tests show that prices and log prices are not stationary. So, the stationarity of prices of $\log$ returns (first difference of logs) is checked by Augmented Dickey-Fuller (ADF) and Phillips-Perron tests. Tests for stationarity assessment are performed on series in first difference. All coefficients of the model are significant. The observation place for a potential break is on February 2009. That is firstly when fuel prices recovered in early 2009 after they plummeted in the second semester of 2008 and secondly when new environmental fuel standards were enforced. These facts help provide an economic interpretation of that date rupture.

Considering all the studied series, unit root with structural break tests result (Zivot and Andrews) in accepting the assumptions of structural changes (see table A2.1). The regression coefficients estimated for the different test specifications are all significant for the specification 'intercept and trend' with $\Delta \ln$ (pbrente) $\Delta \ln$ (pgdoe) and $\Delta \ln$ (pester). Thus, the series expressed in first difference are stationary with a break in level and trend in December 2008 to $\Delta \ln$ (pbrente) and in February 2009 for both products (gasoil and ester) from these raw materials $\Delta \ln$ (pgdoe) and $\Delta \ln$ (pester). The breaks found for a rank of observation outside $[15 \%, 85 \%]$ are not considered. Consequently, the ranks 15 (date of January 2008) and 108 (date of November 2015) found for $\Delta \ln$ (prapeseed) and $\Delta \ln$ (pgdoe) respectively are not considered. So, only are valid the breaks at the bottom oil price (Brent price expressed in euros) in December 2008 and the bottom gasoil diesel price in February 2009, while automotive fuel norms were modified in the EU in January 2009. 
Table A2.1 - Unit-root tests on price series

\begin{tabular}{|c|c|c|c|c|c|}
\hline Test & & $\Delta \ln ($ pbrente $)$ & $\Delta \ln ($ prapeseed $)$ & $\Delta \ln ($ pgdoe $)$ & $\Delta \ln ($ pester $)$ \\
\hline \multirow[t]{3}{*}{$\mathrm{ADF}$} & none & $-5.090 * * *$ & $-5.935 * * *$ & $-4.482 * * *$ & $-5.161 * * *$ \\
\hline & intercept & $-5.076^{* * *}$ & $-5.920 * * *$ & $-4.475 * * *$ & $-5.138 * * *$ \\
\hline & trend & $-5.391 * * *$ & $-5.963 * * *$ & $-4.815 * * *$ & $-5.167 * * *$ \\
\hline \multirow[t]{3}{*}{$\mathrm{PP}$} & none & $-7.121 * * *$ & $-7.962 * * *$ & $-7.500 * * *$ & $-7.652 * * *$ \\
\hline & intercept & $-7.109 * * *$ & $-7.936 * * *$ & $-7.491 * * *$ & $-7.618 * * *$ \\
\hline & trend & $-7.255 * * *$ & $-7.942 * * *$ & -7.722 *** & $-7.621 * * *$ \\
\hline \multirow[t]{6}{*}{$\mathrm{ZA}$} & intercept & $-8.034 * * *$ & $-8.147 * * *$ & $-8.477 * * *$ & $-7.862 * * *$ \\
\hline & date & $\begin{array}{l}\text { December- } \\
08\end{array}$ & February-08 & $\begin{array}{l}\text { November- } \\
15\end{array}$ & January-11 \\
\hline & trend & $-7.662 * * *$ & $-7.858 * * *$ & $-8.338 * * *$ & $-7.644 * * *$ \\
\hline & date & $\begin{array}{l}\text { November- } \\
15\end{array}$ & August-08 & $\begin{array}{l}\text { November- } \\
15\end{array}$ & April-07 \\
\hline & $\begin{array}{l}\text { intercept } \quad+ \\
\text { trend }\end{array}$ & $-8.693^{* * *}$ & $-8.524 * * *$ & $-8.783 * * *$ & $-8.495 * * *$ \\
\hline & date & $\begin{array}{l}\text { December- } \\
08\end{array}$ & December-08 & $\begin{array}{l}\text { February- } \\
09\end{array}$ & $\begin{array}{l}\text { February- } \\
09\end{array}$ \\
\hline
\end{tabular}

Note: DF Augmented Dickey-Fuller test, PP Phillips-Perron test, ZA Zivot-Andrews test. *** significant at the threshold of $1 \%, * * 5 \%, * 10 \%$. The number of lags is determined using the BIC criterion. In the ZA test, the date is the last month of the sub-period before the break

A cointegration analysis was performed between ester gasoil and rapeseed oil prices on the European market. From the Trace test, we show that no cointegration was found over the entire period from November 2006 to January 2016. However, significant results were obtained when the test was performed on a subsample from November 2006 to December 2009, before the rise of ester and rapeseed oil prices in 2010 . 


\section{ESSEC}

BUSINESS SCHOOL

ESSEC Business School

3 avenue Bernard-Hirsch

CS 50105 Cergy

95021 Cergy-Pontoise Cedex

France

Tel. +33 (0)134433000

www.essec.edu

\section{ESSEC Executive Education}

CNIT BP 230

92053 Paris-La Défense

France

Tel. +33 (0)1 46924900

www.executive-education.essec.edu

\section{ESSEC Asia-Pacific}

5 Nepal Park

Tel. +65 68849780

ESSEC | CPE Registration number 200511927D

Period of registration: 30 June 2017 - 29 June 2023

Committee of Private Education (CPE) is part of SkillsFuture Singapore (SSG)

\section{ESSEC Africa}

Plage des Nations - Golf City

Route de Kênitra - Sidi Bouknadel (Rabat-Salê)

Morocco

Tel. +212 (0)5 37824000

www.essec.edu 